\title{
PROBLEMS OF PROTECTION OF URBAN AREAS FROM RADIONUCLIDES STRONTIUM-90 AND CAESIUM-137 AFTER TECHNOLOGICAL DISASTERS
}

\author{
Olga Cheremisina ${ }^{1}$, Vasiliy Sergeev ${ }^{1}$, Alexander Fedorov ${ }^{1}$, Alexandra Iliyna ${ }^{1}$ \\ 1 Saint Petersburg Mining University, Department of General and Physical Chemistry, 21 ${ }^{\text {st }}$ Line 2, 199106 \\ Saint Petersburg, Russia, e-mail: ovcheremisina@yandex.ru, sergeev.spmi@yandex.ru, bers10@bk.ru, \\ alexandra.ilyna@gmail.com
}

Received: 2017.03 .06

Accepted: 2017.04 .05

Published: 2017.05 .02

\begin{abstract}
The methods of decontamination of radionuclides from soils are considered. The literature focuses on fixing radionuclides in soils and creating geochemical barriers that it is prevent the spread of pollution. The main disadvantage of these methods is excluding the possibility of building a territory. It is needed to clean up the area to the sanitary and hygienic requirements for further use and then it is desirable to fix the residual activity. The conducted analysis of forms of radionuclides fixation in soils and mechanics of this fixation, therewith revealed that Cs-137 fixed more strongly on mineral components of soil, than $\mathrm{Sr}-90$, which is mainly in the acid-soluble and exchangeable form, and, as a consequence, passes into the liquid phase during soil deactivation more easily. Contaminated soil deactivation in the urbanized territory is possible by washing it by ferric chloride solution at a concentration $0.02-0.05 \mathrm{M}$ and with an equimolar addition of an ammonium chloride. Therewith, most efficient methods, which use in-situ conditions, are heap and convection leaching technologies with treatment degree, which is not less than $80 \%$. At the same time, the most efficient methods which use in-situ conditions are heap and the convection leaching. The hardware-technological scheme of a convection leaching is presented. It is worth to note that ammonium salts additions slightly rise coefficient of treatment from Sr-90. Because ammonium salts are inexpensive, their additions allow to obtain significant economic benefits due to decreasing ferric chloride consumption, which is more valuable, and waste water volume reduction.
\end{abstract}

Keywords: Strontium-90, Caesium-137, decontamination of radionuclides, elution of radionuclides, convection leaching, heap leaching

\section{INTRODUCTION}

Near the nuclear facilities the radiation pollution of a territory is due to by emission of the isotopes Cs-137 and $\mathrm{Sr}-90$ as the products of nuclear decay. In urban areas, the deactivation of contaminated territory takes the degree of the radiation pollution of the soil and the migration mobility of isotopes Cs-137 and Sr -90 into account with the aim for further building in these territories. At the same time, the ground used shall comply with the sanitary and hygienic re- quirements in respect of building matters which may be used in the base of buildings.

Generally, the lowest level of specific radioactivity is $1.2 \times 10^{-6} \mathrm{Ci} / \mathrm{kg}$, established for the solid radioactive waste. The building is forbidden with contamination levels of beta-rays from $1.2 \times 10^{-6}$ to $2 \times 10^{-6} \mathrm{Ci} / \mathrm{kg}$, but it is possible final deposition in the reverse-well disposals. The large volumes of ground are generated in urban areas with the large-scale radiation pollution. Such volumes are difficult to disposal. Therefore, cleaning from radionuclides of urban areas is an urgent issue. 


\section{METHODS OF DECONTAMINATION SOILS FROM RADIONUCLIDES}

The literature focuses on fixing radionuclides in soils and creating barriers that it is prevent the spread of pollution. There are different types of geochemical barriers to the migration of cations of heavy metals, including radionuclides:

1. The coagulation-based thin suspensions [Mao et al, 2015];

2. The physicochemical barriers - precipitation under the action of a sharp violation of acidbase or oxidation-reduction regimes [Choppin et al, 2002];

3. The biogeochemical barriers [Newsome et al, 2014];

4. The Sorption barriers [ Mao et al, 2015];

5. The thermodynamic barriers - deposition under the influence of temperature and pressure changes [Grivé et al, 2015]

The simplest way of fixing Sr-90 is liming the ground. There are other ways of fixation: the cation-exchange membranes [Ambashta and Sillanpää, 2012] and the ecological concreting [Shi and Fernández-Jiménez, 2006.] On the other hand, the disadvantage of these methods is excluding the possibility of building a territory. It is necessary to clean up the area to the sanitary and hygienic requirements for further use and then it is desirable to fix the residual activity. Consequently, deactivation of very contaminated soil and dilution of less contaminated one with clean materials up to current standards are more realistic.

Elution soil leaching would be the simplest and cheapest way of soil deactivation. Possibility of radionuclide removal from soil has been researched for many years [Sawhney, 1972.]. Cesium-137 is hardly removed from soil by $1 \mathrm{M}$ am-

Table 1. Results of leaching of silts from river Techa of strontium-90

\begin{tabular}{|l|c|c|}
\hline \multicolumn{1}{|c|}{ Eluent } & Concentration & $\begin{array}{c}\text { Purification } \\
\text { degree, } \%\end{array}$ \\
\hline Distilled water & - & 15.1 \\
\hline Main water & - & 18.0 \\
\hline Hydrogen nitrate & $0.1 \mathrm{M}$ & 56.8 \\
\hline Hydrogen nitrate & $0.2 \mathrm{M}$ & 68.6 \\
\hline Hydrogen nitrate & $0.5 \mathrm{M}$ & 72.5 \\
\hline Hydrogen nitrate & $1.0 \mathrm{M}$ & 74.5 \\
\hline $\mathrm{H}_{2} \mathrm{O}_{2}$ & $34 \%$ & 59.2 \\
\hline $\mathrm{NaOH}$ & $1.3 \mathrm{M}$ & 2.7 \\
\hline $\mathrm{FeCl}_{3}+\mathrm{NH}_{4} \mathrm{Cl}$ & $0.01 \mathrm{M}$ & 85.0 \\
\hline
\end{tabular}

monium acetate and hydrochloric acid solutions, $0.01 \mathrm{M}$ sodium ethylenediaminetetraacetate (Trilon B) solution and bird-cherry extract, birch and aspen, potassium and cesium salts' solutions.

Cesium-137 desorption during soil leaching with salts and acids was researched in papers [Titlyanova, 1963; Rogozin et al, 1994]. As a result of soil leaching with salts' and acids' solutions, cesium-137 is desorbed for no more than $30 \%$, likely, only from surface of the mineral. Humates are a non-exchangeable form of cesium in soil. Organic complexes do not extract cesium from soil at all. Boiling treatment with $6 \mathrm{M}$ hydrogen nitrate, where organic and some mineral components of soil are degraded, is the only known way of cesium-137 desorption.

Possibility of strontium-90 leaching from soil was researched in the paper [Chuveleva, 1996]. Objects of the research were silts from river Techa in Chelyabinsk region (Table 1). It was found out that strontium in silts is bonded significantly less competent than cesium. Around $15 \%$ of strontium-90 was in researched objects of silts in water-soluble form and could be leached just with water. Around $70 \%$ of radionuclides were in ionexchangeable form and went over to dilute solutions of acids and salts. Only around $15 \%$ of strontium-90 were fixed in non-ion-exchangeable form.

In spite of high concentration of organic fraction, silts leaching from radionuclides reaching purification degree above $70 \%$ is possible with hydrogen nitrate solutions. Thus, to solve the task of effective soil leaching, it is necessary to research forms of radionuclides' fixation in soil and mechanism of its belaying.

\section{FORMS OF FIXATION OF RADIONUCLIDES ${ }^{137}$ CS AND ${ }^{90}$ SR IN SOIL}

Authors of the paper [Lisin et al, 1993] researched physicochemical forms of ${ }^{90} \mathrm{Sr}$ and ${ }^{137} \mathrm{Cs}$ in soil of western area of Bryansk region, which was influenced by Chernobyl nuclear disaster. Research results of radionucludes' sorption in sod-podzolic sabulous soil of western area in Bryansk region are shown in tables 2 and 3.

Comparison of the results allows to conclude that mobility of $90 \mathrm{Sr}$ is significantly higher than $137 \mathrm{Cs}$ mobility. As a result, main forms of $90 \mathrm{Sr}$ in sod-podzolic sabulous soil are exchangeable and acid-soluble forms. Furthermore, percentage of mobile forms of $90 \mathrm{Sr}$ is $40-90 \%$, which is higher 
Table 2. Physicochemical forms of ${ }^{137} \mathrm{Cs}$ in soil

\begin{tabular}{|c|c|c|c|c|c|}
\hline \multirow{2}{*}{ No. } & \multirow{2}{*}{ Layer, sm } & \multicolumn{5}{|c|}{ Forms, \% } \\
\cline { 3 - 6 } & & water-soluble & exchangeable & acid-soluble & fixed \\
\hline 1 & $0-5$ & 0.2 & 0.4 & 5.9 & 93.5 \\
\hline 2 & $0-5$ & 0.08 & 1.1 & 3.8 & 95.0 \\
\hline 3 & $0-5$ & 0.1 & 0.9 & 3.8 & 95.2 \\
\hline 4 & $0-5$ & 0.06 & 0.2 & 0.9 & 98.9 \\
\hline 5 & $0-5$ & 0.05 & 0.4 & 1.7 & 97.9 \\
\hline 6 & $0-5$ & 0.6 & 1.0 & 5.9 & 92.6 \\
\hline 7 & $0-5$ & 0.04 & 1.2 & 9.2 & 89.6 \\
\hline 8 & $0-5$ & 0.3 & 7.9 & 11.3 & 80.5 \\
\hline 9 & $6-10$ & 0.4 & 3.8 & 8.3 & 87.4 \\
\hline
\end{tabular}

Table 3. Physicochemical forms of ${ }^{90} \mathrm{Sr}$ in soil

\begin{tabular}{|c|c|c|c|c|c|}
\hline \multirow{2}{*}{ No. } & \multirow{2}{*}{ Layer, sm } & \multicolumn{4}{|c|}{ Forms, \% } \\
\cline { 3 - 6 } & & water-soluble & exchangeable & acid-soluble & fixed \\
\hline 1 & $0-5$ & 2.3 & 76.0 & 17.0 & 4.7 \\
\hline 2 & $0-5$ & 3.0 & 61.1 & 31.8 & 4.1 \\
\hline 3 & $0-5$ & 5.6 & 46.8 & 41.5 & 6.1 \\
\hline 4 & $0-5$ & 10.4 & 48.6 & 25.5 & 15.5 \\
\hline 5 & $0-5$ & 8.8 & 46.7 & 26.3 & 18.3 \\
\hline 6 & $0-5$ & 3.1 & 49.7 & 22.9 & 3.3 \\
\hline 7 & $0-5$ & 1.0 & 88.0 & 7.7 & 11.3 \\
\hline 8 & $0-5$ & 22.3 & 47.4 & 19.0 & 10.0 \\
\hline 9 & $6-10$ & 11.9 & 52.4 & 25.7 & 18.8 \\
\hline 10 & $10-18$ & 14.6 & 43.8 & 22.9 & \\
\hline
\end{tabular}

than mobile forms of $137 \mathrm{Cs}$ on single-order and it is responsible for high radiation danger.

So, main part of $137 \mathrm{Cs}$ is fixed as a result of irreversible ion sorption with soil particles via insertion into minerals' lattice, also clayey. Moreover, it is pointed out in a lot of papers [Virchenko et al 1993; Varshal et al 1996; Zakharov et al 2001; Kuznetsov and Payne et al 2000; Martjushov et al 1995] that during sorption process of $137 \mathrm{Cs}$ amorphous films are of significant importance. They form ferric and aluminum hydroxides and organic elements (humic and fulvic acids) on the surface of the soil particles.

Authors of the paper [Martjushov et al 1995] researched forms of state and deportment of radionuclides in soil of Eastern-Ural radioactive trail, 36 years after the accident. Using ion-exchangeable resins, the authors determined anionic, cationic and neutral forms of radionuclides in water extract.

It is obvious from the table that $90 \mathrm{Sr}$ is bonded less competent, because the concentration of its fixed forms in soil does not go above 34\%, while $137 \mathrm{Cs}$ concentration is about three times higher (95-99\% of total ratio).
The conducted researches allow to conclude, that Cs-137 fixed on mineral component of soil more strongly than $\mathrm{Sr}-90$, consequently $\mathrm{Sr}-90$ is more mobile and will be easier to go into liquid phase in the process of the ground deactivation. Additionally, the feature of Sr-90 is the preferential fixation in complexes with fulvic acids, and $\mathrm{Cs}-$ with humic acids.

Common patterns in dynamic of radionuclide fixation in soil are as follows: transition of radionuclides in nonexchangeable state the more intense, the higher concentration of humus, silt fraction and exchangeable cations. In course of time in soil redistribution of mobile form of radionuclides is taking place from areas with low bond energy to areas with more strong, specific sorption.

\section{ELUTION WASH OF SOILS FROM RADIONUCLIDE CONTAMINATION}

Removal of radionuclides from soils is possible by applying ion exchange of their cations for cations with stronger throwing power. Lastnamed (throwing power) proportional to cation 
Table 4. Forms of radionuclides in soil, $\%$ of total ratio

\begin{tabular}{|c|c|c|c|c|c|c|c|c|}
\hline \multirow{2}{*}{ Soil } & \multicolumn{4}{|c|}{${ }^{137} \mathrm{Cs}$} & \multicolumn{4}{|c|}{${ }^{90} \mathrm{Sr}$} \\
\hline & $A$ & B & $\mathrm{C}$ & $\mathrm{D}$ & $A$ & B & C & $D$ \\
\hline Sod-podzolic & 0.2 & 0.4 & 0.4 & 99.0 & 2.5 & 45.8 & 44.2 & 7.5 \\
\hline Sod-podzolic + grey forest & 0.03 & 2.87 & 0.5 & 96.6 & 2.0 & 23.4 & 73.6 & 1.0 \\
\hline Grey + dark-grey forest & 0.02 & 1.18 & 2.7 & 95.1 & 2.4 & 58.0 & 30.0 & 9.6 \\
\hline $\begin{array}{l}\text { Chernozem + meadow } \\
\text { chernozem }\end{array}$ & 0.1 & 1.1 & 2.1 & 96.6 & 1.8 & 55.9 & 30.9 & 11.4 \\
\hline Alluvial-lacustrine & 0.03 & 1.47 & 1.7 & 96.8 & 1.2 & 38.8 & 26.0 & 34.0 \\
\hline Peaty-bog & 0.2 & 1.4 & 2.9 & 95.5 & 2.9 & 43.3 & 32.0 & 21.8 \\
\hline
\end{tabular}

Notice: A- water soluble; B- exchange; C- acid soluble ; D-fixed.

charge and inversely proportional to its radius in hydrated state. On these parameters $\mathrm{Fe}^{3+}$ was selected as an ion-displacer.

Selection of salt's anion had the following reasons. Salts of weak acids are unsuitable because of irreversible hydrolysis. Sulfate ions exerts masking effect on iron cations because of complex formation. Ferric nitrates $(3+)$ unstable and unsuitable for agrochemical standards. For this reason, authors [Chirkst et al. 2001] for the function of eluent selected ferric chloride (3+) solution with ammonium chloride addition for $\mathrm{pH}$ stabilization and for non-isotopic carrier for Ce-137.

During in-situ testing in Bryansk region it was found that soil treatment from Ce-137 radionuclides is carried out satisfactory under eluent concentration $0.02 \mathrm{M}$. In laboratory degree of treatment amounted to over $90 \%$ on model solution and $70 \%$ on real samples of contaminated soil. Further, during in-situ testing degree of treatment of the land plot with an area of $10 \mathrm{~m}^{2}$ was achieved at $50 \%$. The results of model soil samples, in other words artificially contaminated, treatment from $\mathrm{Sr}-90$ is presented in Table 5.

Table 5. Results of model soil samples treatment

\begin{tabular}{|c|c|c|c|}
\hline Eluent & Concentration & $\mathrm{ml} / \mathrm{g}$ & $\begin{array}{c}\text { Treatment } \\
\text { degree, \% }\end{array}$ \\
\hline $\mathrm{FeCl}_{3}$ & 0.1 & 5 & 88 \\
\hline $\begin{array}{c}\mathrm{FeCl}_{3}+ \\
\mathrm{NH}_{4} \mathrm{Cl}\end{array}$ & 0.05 & 5 & 80 \\
\hline $\mathrm{FeCl}_{3}$ & 0.05 & 5 & 70 \\
\hline $\mathrm{HCl}$ & 0.01 & 5 & 25 \\
\hline $\mathrm{NH}_{4} \mathrm{Cl}$ & 0.05 & 5 & 20 \\
\hline $\mathrm{FeCl}_{3}$ & $0.1 \mathrm{M}$ & 10 & 95 \\
\hline $\begin{array}{c}\mathrm{FeCl}_{3}+ \\
\mathrm{NH}_{4} \mathrm{Cl}\end{array}$ & $0.05 \mathrm{M}$ & 10 & 90 \\
\hline $\mathrm{FeCl}_{3}$ & $0.05 \mathrm{M}$ & 10 & 68 \\
\hline $\mathrm{HCl}^{\mathrm{N}}$ & $0.01 \mathrm{M}$ & 10 & 50 \\
\hline $\mathrm{NH}_{4} \mathrm{Cl}$ & $0.05 \mathrm{M}$ & 10 & 25 \\
\hline
\end{tabular}

Therethrough, soil treatment from radionuclides of $\mathrm{Ce}$ and $\mathrm{Sr}$ is possible by washing it by ferric chloride solution at a concentration $0.02-0.05 \mathrm{M}$ and with an equimolar addition of a ammonium chloride. Authors [Chirkst et al. 2002] have revealed that soil treatment degree by applying ferric chloride solution significantly more than solutions of ammonium chloride or hydrochloric acid. Furthermore, treatment degree is rising with increasing eluent concentration and with addition of ammonium chloride. Composition of eluents which used for sample washing and treatment coefficients is presented in Table 6.

It is worth to note that ammonium salts additions (chloride or nitrate) slightly rise coefficient of treatment from Sr-90. Because ammonium salts are inexpensive, their additions allow to obtain significant economic benefits due to decreasing of ferric chloride consumption, which is more valuable, and waste water volume reduction. In such case ammonium cation acts as non-isotopic carrier for $\mathrm{Cs}$ in solution and prevents re-fixation of an isotope in soil.

As a result following eluents are recommended: 1. Nitric acid solution at $0.5 \mathrm{M}$ concentration.

2. Equimolar solution of ferric chloride and ammonium soil (chloride or nitrate) at $0.5 \mathrm{M}$ concentration.

\section{APPROBATION OF PROCESS MODELS IN-SITU}

Most efficient methods which used in-situ conditions are heap and convection leaching (Figure 1) [Chirkst et al. 2001]. Ore heap leaching technology is well developed, particularly, in St. Petersburg Mining Institute, and successfully applied for non-ferrous metals recovery from lean ore and tailings, when other technologies are not economically irrational. 
Table 6. Coefficients of soil treatment from $\mathrm{Sr}-90$

\begin{tabular}{|c|c|c|c|c|c|}
\hline Sample number & Eluent & Concentration, $\mathrm{M}$ & $\mathrm{V} / \mathrm{m}$, & $\begin{array}{c}\text { Treatment degree, } \\
\%\end{array}$ & $\begin{array}{c}\text { Treatment } \\
\text { coefficient }\end{array}$ \\
\hline 1 & Trilon $\mathrm{B}$ & 0.05 & 6 & 43 & 1.76 \\
\hline 2 & Trilon $\mathrm{B}$ & 0.025 & 15 & 41 & 1.69 \\
\hline 3 & $\begin{array}{c}\text { trilon, } \\
\mathrm{pH}=12\end{array}$ & 0.025 & 10 & 37 & 1.58 \\
\hline 4 & $\mathrm{FeCl}_{3}$ & 0.15 & 14 & 94.7 & 19 \\
\hline 5 & $\mathrm{HNO}_{3}$ & 0.1 & 5 & 97.8 & 46 \\
\hline 6 & $\mathrm{HNO}_{3}$ & 0.5 & 6 & 96.6 & 29 \\
\hline 7 & $\mathrm{HNO}_{3}$ & 0.5 & 9 & 96.8 & 31 \\
\hline 8, neutr. $\mathrm{pH}=3$ & $\mathrm{FeCl}_{3}+\mathrm{NH}_{4} \mathrm{NO}_{3}$ & 0.02 & 5 & 94.2 & 17 \\
\hline 10, neutr. $\mathrm{pH}=3$ & $\mathrm{FeCl}_{3}$ & 0.03 & 5 & 95.6 & 23 \\
\hline $11, \mathrm{pH}=3$ & $\mathrm{FeCl}_{3}+\mathrm{NH}_{4} \mathrm{NO}_{3}$ & 0.04 & 5 & 97.2 & 35 \\
\hline 12, neutr. $\mathrm{pH}=3$ & $\mathrm{FeCl}_{3}$ & 0.05 & 5 & 97.7 & 44 \\
\hline 13, neutr. $\mathrm{pH}=3$ & $\mathrm{FeCl}_{3}+\mathrm{NH}_{4} \mathrm{Cl}$ & 0.02 & 10 & 93.2 & 15 \\
\hline
\end{tabular}

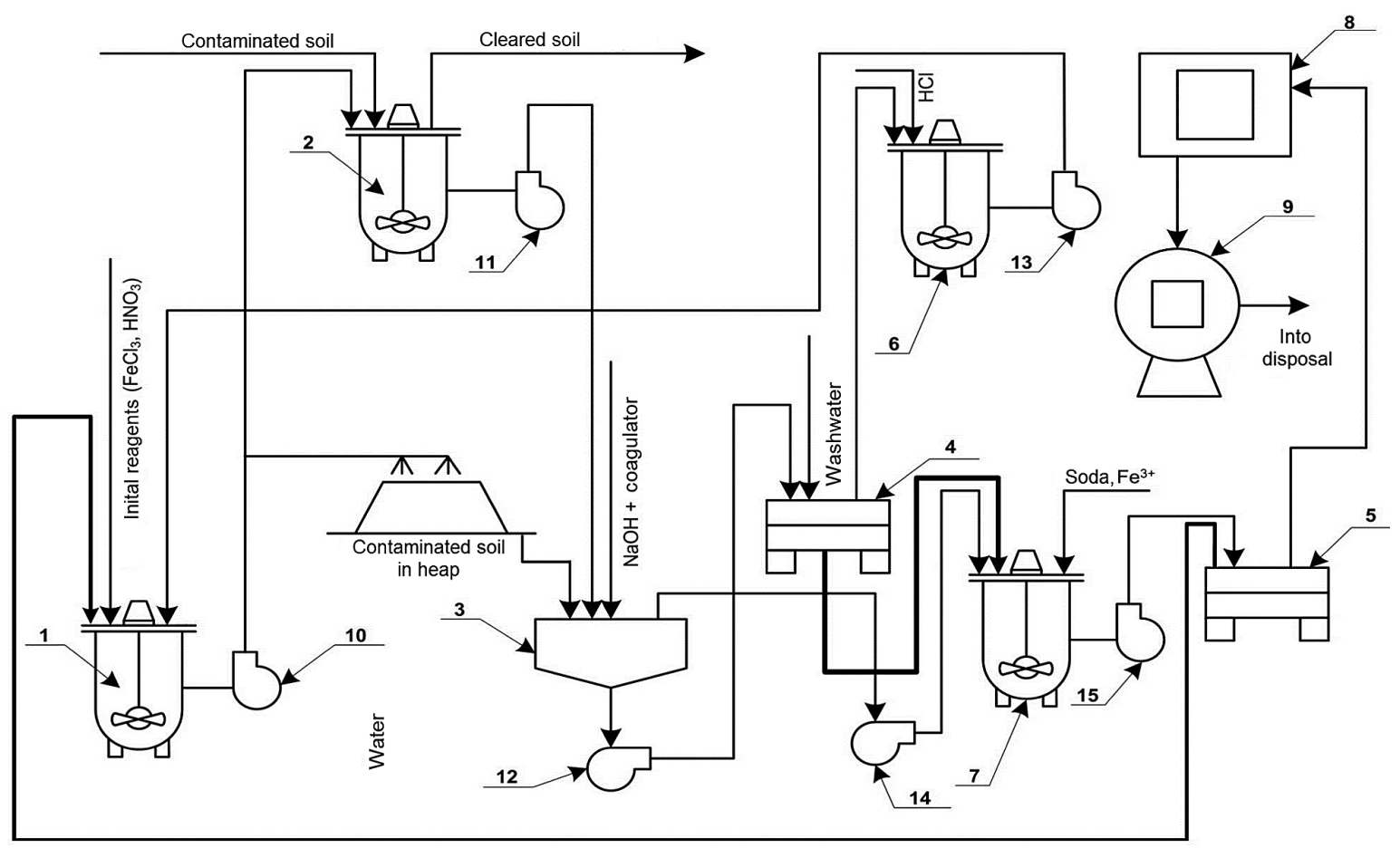

1 - Reactor for washing solution prepairing; 2 - Convectional leaching reactor; 3 - Ferric hydroxide settling unit; 4,5 Plate-and-frame press; 6 - Ferrum recovery tank; 7 - Strontium carbonate precipitation reactor; 8 - Drying unit; 9 Calcination furnace; $10-15$ - Centryfugal pump

Figure 1. The hardware-technological scheme of a convection leaching

Heap leaching includes following operations [Chirkst et al 2001]:

1. Initial material is piled up on a moisture-proof concrete platform equipped with drainage channels. The dimensions of a heap are calculated in accordance with soil rheological properties research.

2. Heap periodically irrigates with eluent, which protects it from drying out by a polyethylene film. Eluting solution is slowly filtered through the heap, leaching contaminants under dynamic equilibration conditions.

3. Wash water is collected to a water receiver then headed to neutralization and treatment. Material in the heap is periodically refreshed.

Heap leaching has following drawbacks: 1. Low intensity, i.e. process reaction rate. 
2. Presence of sticking, lumping of soil which leads to unequal washing. It is also possible to form areas, which are not inaccessible for eluent. For this reason soil treatment degree is worse.

Another technological method of soil treatment provides higher treatment degree - washing in batch action installations with active phase mixing - convectional leaching [Dibrov 2000]. Operating principle - separation and disposal of finely divided radionuclides enriched soil fraction.

\section{CONCLUSION}

The conducted analysis of forms of radionuclides fixation in soils and mechanics of this fixation, therewith revealed that Cs-137 fixed more strongly on mineral component of soil, than Sr-90, which is mainly in the acid-soluble and exchangeable form, and, as a consequence, passes into the liquid phase during soil deactivation more easily. Contaminated soil deactivation in the urbanized territory is possible by washing it by ferric chloride solution at a concentration $0.02-0.05 \mathrm{M}$ and with an equimolar addition of a ammonium chloride. Therewith most efficient methods, which used in-situ conditions, are heap and convection leaching technologies with treatment degree, which are not less than $80 \%$.

\section{REFERENCES}

1. Ambashta R., Sillanpää M. Membrane purification in radioactive waste management: a short review. Journal of Environmental Radioactivity,105,76-84.

2. Bondar Yu.I., Zabrodsky V.N. 2001. Sorbtsiya ionnykh form 90Sr i 137Cs razlichnymi tipami pochv (Sorption of the ionic forms of $90 \mathrm{Sr}$ and $137 \mathrm{Cs}$ by different types of soils). Radiokhimiya, 43 (6), 566-568.

3. Chirkst D.E., Litvinova T.E., Cheremisina O.V., Streleckaja M.I. 2001. Opytnaja tehnologija dezaktivacii gruntov, zagrjaznennyh radionuklidom $\mathrm{Sr}$ 90 / D (Experienced technology of decontamination of soils contaminated by radionuclide $\mathrm{Sr}-90)$. Radiohimija, 43(5), 475-478.

4. Chirkst D.E., Litvinova T.E., Cheremisina O.V. 2002. Povedenie 137Cs v processe dezaktivacii grunta 5-go kvartala Vasil'evskogo ostrova (The behavior of $137 \mathrm{Cs}$ in the process of decontamination of the soil of the 5th quarter of Vasilievsky is- land). Radiohimija, 44( 4), 378-381.

5. Choppin G., Liljenzin J-O., Rydberg J. 2002. Behavior of Radionuclides in the Environment. Radiochemistry and Nuclear Chemistry (Third Edition), 22, 642-673.

6. Chuveleva E.A., Firsova L.A. Et al. Radiokhimiya, 1996, 38 (6), 554-557.

7. Dibrov I.A. 2000. Opytnaja tehnologija ochistki gruntov ot zagrjaznenija radionuklidami((Experienced technology of cleaning soil from pollution by radionuclides). Jekologija i razvitie stran Baltijskogo regiona. 121 - 126.

8. Grivé M., Duro L., Colàs E., Giffaut E. 2015. Thermodynamic data selection applied to radionuclides and chemotoxic elements: An overview of the ThermoChimie-TDB. Applied Geochemistry, 55, 85-94.

9. Konoplev A.V., Comans R.N.J., Hilton J. 1996. The Radiolodical Consequences of the Chernobyl Accident, 121-135.

10. Kuznecov V.A., Generalova V.A. 2000. Issledovanie sorbcionnyh svojstv gidroksidov zheleza, marganca, titana, aljuminija i kremnija po otnosheniju k Sr-90 i Cs-137 (Study of sorption properties of the hydroxides of iron, manganese, titanium, aluminum and silicon in relation to $\mathrm{Sr}-90$ and Cs137). Radiohimija, 42( 2), 154-157.

11. Lisin S.K., Simirskaya G.P., Simirsky Yu.N., Rodionov Yu.F., Shubko V.M. 1993. Formy nakhozhdeniya Cs-137 i Sr-90 v pochvakh Bryanskoj oblasti (Forms of the presence of Cs-137 and Sr90 in the soils of the Bryansk region). Radiatsiya $i$ risk, 3, 129-132.

12. Mao X, Jiang R., Yu J. 2015. Use of surfactants for the remediation of contaminated soils: A review. Journal of Hazardous Materials, 285, 419-435.

13. Martjushov V.V., Spirin D.A., Bazilev V.V., Fedorova T.A. 1995. Sostojanie radionuklidov v pochvah Vostochno-Ural'skogo radioaktivnogo sleda (The state of radionuclides in soils of the EasternUrals radioactive trace). Jekologija, 2, 110-113.

14. Newsome L., Morris K., Lloyd J.R. 2014. The biogeochemistry and bioremediation of uranium and other priority radionuclides. Chemical Geology, 363, 164-184.

15. Pavlotskaya F.I. 1974. Migratsiya radioaktivnykh produktov global'nykh vypadenij v pochvakh (Migration of radioactive products of global fallout in soils). Moscow: Atomizdat

16. Rogozin Yu.M. Et al. Radiokhimiya, 1993, 35(2), 149-153.

17. Sawhney B.L. 1972. Selective sorpsion and fixation of cations by clay minerals: a review. Clays and Clay Minerals, 20, 93-100.

18. Shi C., Fernández-Jiménez A. 2006. Stabilization/ 
solidification of hazardous and radioactive wastes with alkali-activated cements. ournal of Hazardous Materials, 137(3), 1656-1663.

19. Sawhney B.L.1972. Selective sorpsion and fixation of cations by clay minerals: a review. Clays and Clay Minerals, 20, 93-100.

20. Titlyanova A.A.1964. Pochvovedenie, 12, 88-94.

21. Varshal G.M., Koshheeva N.Ja., Veljuhanova T.K., Chhetija D.N., Tjutjunnik O.A., Grinevskaja Zh.M. 1996. Sorbcija tjazhelyh metallov i izotopnyh nositelej dolgozhivushhih radionuklidov na G.K.: Soobshhenie 1. Sorbcija cezija (I), stroncija(II), cerija (III), rutenija (IV) na guminovoj kislote (Sorption of heavy metals and isotopic carriers of long-lived radionuclides.) Geohimija, $11,1107-1112$.

22. Virchenko E.P., Agapkina G.I. 1993. Radionuklidorganicheskie soedinenija $\mathrm{v}$ pochvah zony vlijanija ChAJeS (Radionuclide-organic compounds in the soils of the zone of influence of Chernobyl). Pochvovedenie, 1, 13-17.

23. Zaharova E.V., Kajmin E.P., Darskaja E.N., Menjajlo K.A., Zubkov A.A. 2001. Rol' fiziko-himicheskih processov pri dolgovremennom hranenii zhidkih RAO v glubinnyh plastah-kollektorah (The role of physico-chemical processes during long-term storage of liquid waste in deep reservoirs). Radiohimija, 43(4), 213-221. 